\title{
PENERAPAN MODEL PROBLEM BASED LEARNING (PBL) DENGAN PENDEKATAN SAINTIFIK UNTUK MENINGKATKAN HASIL BELAJAR SISWA PADA MATERI ASAM BASA
}

\author{
oleh \\ LA RUDI ${ }^{1}$, MUH. ALIM MARHADI ${ }^{1}$, ACI $^{2}$ \\ ${ }^{1}$ Dosen Fakultas Keguruan dan Ilmu Pendidikan Universitas Halu Oleo, \\ ${ }^{2}$ Alumni Pendidikan Kimia FKIP UHO \\ Email: larudi.fkip@uho.ac.id
}

\begin{abstract}
ABSTRAK
Telah dilakukan penelitian "Penerapan Model Problem Based Learning (PBL) dengan Pendekatan Saintifik untuk Meningkatkan Hasil Belajar Siswa pada Materi Asam Basa" yang dilaksanakan di SMAN 7 Kendari pada kelas XI MIA 3 tahun ajaran 2018/2019. Penelitian ini bertujuan untuk mengetahui bagaimana pengaruh penerapan model PBL dengan pendekatan saintifik dalam meningkatkan hasil belajar siswa kelas XI MIA SMA Negeri 7 Kendari pada materi asam basa. Metode penelitian yang digunakan yaitu Pre-Eksperimen dengan desain penelitian One-group Pretest-Postest Design. Teknik pengumpulan data dilakukan dengan pemberian instrumen penelitian berupa soal pilihan ganda berjumlah 20 butir soal, lembar observasi dan angket. Berdasarkan hasil analisis data diperoleh kesimpulan: (1) Hasil belajar kimia siswa kelas XI MIA 3 pada SMA Negeri 7 Kendari Tahun Ajaran 2018/2019 sebelum pembelajaran dengan menggunakan model PBL dengan pendekatan saintifik dikategorikan rendah dengan nilai rata-rata pre-test yaitu 29,42 akan tetapi setelah pembelajaran dengan menggunakan model PBL dengan pendekatan saintifik dikategorikan sedang dengan nilai rata-rata post-test sebesar 78,46; (2) Penerapan model PBL dengan saintifik pada materi asam basa efektif dalam meningkatkan hasil belajar siswa dengan rata-rata $\mathrm{N}$ gain sebesar 0,70 (kategori sedang); (3) Siswa memberikan respon yang sangat baik terhadap penerapan model PBL dengan pendekatan saintifik dengan nilai rata-rata sebesar $82,95 \%$.
\end{abstract}

Kata Kunci: Problem Based Learning, Pendekatan Saintifik, Asam Basa, Hasil Belajar

PENDAHULUAN

Proses pembelajaran memegang peranan penting dalam meningkatkan mutu pendidikan, semakin baik kualitas proses pembelajaran maka akan meningkat mutu pendidikan.Kualitas proses pembelajaran dapat dilihat dari aktivitas belajar siswa dan pemahaman siswa berdasarkan dari indikator yang harus dicapai serta kinerja guru yang mendukung proses pembelajaran. Implementasi kurikulum 2013 dalam pembelajaran merupakan salah satu bagian dari proses peningkatan mutu pendidikan. Proses pembelajaran kurikulum 2013 diterapkan dengan pendekatan ilmiah (Scientific Approach). Pendekatan ini lebih menekankan keaktifan siswa dengan menggunakan model pembelajaran penemuan (discovery/inquiry learning), pembelajaran berbasis proyek (project- 
based learning), dan pembelajaran berbasis masalah (problem-based learning, inquiry learning). Penerapan model dengan pendekatan saintifikpada pembelajaran kurikulum 2013 bertujuan agar siswa dapat belajar secara mandiri sehingga proses pembelajaran sudah tidak berpusat pada guru tapi lebih berpusat pada siswa (Kemendikbud, 2013).

Pemilihan pendekatan dan model pembelajaran yang sesuai dengan konsep yang akan disampaikan merupakan hal yang harus diperhatikan guru guna meningkatkan hasil belajar siswa, khususnya pembelajaran kimia. Dalam pemilihan model pembelajaran yang digunakan oleh guru perlu memperhatikan beberapa hal seperti materi yang disampaikan, tujuan pembelajaran, waktu yang tersedia, jumlah siswa, fasilitas dan kondisi siswa dalam pembelajaran serta hal-hal yang berkaitan dengan keberhasilan siswa dalam proses pembelajaran (Suryabrata, 2010).

Kimia merupakan ilmu yang termasuk dalam rumpun Ilmu Pengetahuan Alam (IPA) yang menjelaskan tentang komposisi, struktur, sifat-sifat, dan perubahan materi, serta energi yang menyertai perubahan materi tersebut. Mempelajari ilmu kimia sebagai salah satu mata pelajaran eksakta oleh sebagian siswa memandang kimia sebagai bidang studi yang sangat sulit dan kurang disukai siswa. Mata pelajaran kimia dianggap sulit oleh siswa, karena menyangkut reaksi-reaksi kimia dan perhitungan serta menyangkut konsep-konsep yang bersifat abstrak (Wang, 2014).

Salah satu pokok bahasan dalam pembelajaran kimia di SMA adalah Asam Basa. Kompetensi dasar yang ada pada pokok bahasan asam basa yaitu memahami konsep asam basa serta kekuatannya dan kesetimbangan pengionannya serta menentukan trayek perubahan $p \mathrm{H}$ beberapa indikator yang di ekstrak dari bahan alam. Untuk mencapai kompetensi tersebut diperlukan model pembelajaran yang relevan, yaitu siswa diajak untuk melihat keeratan hubungan antara konsep yang dipelajari dengan fakta dalam kehidupan sehari-hari. Pembelajaran pada materi asam basa, siswa dapat diajak untuk mengamati fenomena larutan asam basa dalam kehidupan sehari-hari dan diajak untuk melakukan percobaan sehingga siswa terlibat langsung dengan sekitarnya.

Hasil observasi awal di SMA Negeri 7 Kendari diperoleh bahwa dalam proses pembelajaran kimia, guru cenderung menggunakan metode ceramah, tanpa pemberian pengalaman langsung kepada siswa, akibatnya siswa kurang aktif, siswa banyak bermain dikelas dan tidak memperhatikan guru. Pembelajaran hanya didominasi oleh kegiatan membaca, mencatat dan mendengarakan penjelasan guru, Selain itu, siswa juga jarang melakukan praktikum karena kurangnya ketersediaan bahan. Informasi yang diperoleh dari Guru Kimia di SMA Negeri 7 Kendari bahwa pelajaran kimia sulit dipahami terutama pada materi yang berisi konsep dan perhitungan matematis seperti pada materi asam basa. Kesulitan siswa dalam memahami konsep asam basa dapat dilihat dari rendahnya hasil belajar siswa. Nilai rata-rata hasil evaluasi ulangan harian siswa pada Tahun Ajaran 2016/2017 adalah 66,04. Selanjutnya nilai rata-rata Tahun Ajaran 2017/2018 adalah 68,15. Nilai tersebut belum memenuhi nilai KKM yang ditetapkan sekolah yaitu 75 . 
Berdasarkan permasalahan diatas maka perlu upaya penanganan untuk menyelesaikan permasalahan yang dihadapi tersebut. Langkah yang dapat dilakukan adalah penerapan model pembelajaran dengan pendekatan yang melibatkan siswa secara aktif yang diharapkan dapat meningkatkan hasil belajar siswa. Salah satu model pembelajaran yang dapat diterapkan guna memudahkan pemahaman siswa adalah model Problem Based Learning (PBL). Model Problem Based Learning merupakan sebuah pembelajaran yang menuntut siswa untuk mengkonstruksi pengetahuan mereka sendiri melalui permasalahan. Model Problem Based Learning dapat menunjang materi asam basa karena aplikasi materi ini erat hubungannya dengan kehidupan seharihari sehingga masalah yang akan diberikan familiar oleh siswa.

Model Problem Based Learning memiliki ciri-ciri pembelajaran yang diawali dengan masalah, biasanya masalah memiliki konteks dengan dunia nyata, siswa secara berkelompok aktif merumuskan masalah dan mengidentifikasi kesenjangan pengetahuan mereka, mempelajari dan mencari sendiri materi yang terkait dengan masalah, dan melaporkan solusi dari masalah (Amir, 2010). Kelebihan dari model Problem Based Learning yaitu dapat mengembangkan kemampuan siswa untuk berpikir kritis dan kreatif, meningkatkan motivasi belajar siswa melalui pengaplikasian konsep pada masalah, menjadikan siswa aktif dan belajar yang lebih mendalam, memungkinkan untuk membangun keterampilan dalam pemecahan masalah, meningkatkan pemahaman melalui dialog dan diskusi dalam kelompok, menjadi pembelajar yang mandiri (Sutirman, 2013)
Hasil Penelitian yang dilakukan oleh Agustianingsi (2015) diperoleh bahwa penerapan model pembelajaran Problem Based Learning pada materi hidrokarbon siswa kelas XI MIA 2 SMA Negeri 6 Kendari dapat meningkatkan hasil belajar siswa, dengan rata-rata $N$ gain sebesar 0,67 yang termasuk dalam kategori sedang.Selain itu, Anggun Purnama sari, dkk (2018) dalam penelitiannya menyimpulkan bahwa model Problem Based Learning efektif dalam meningkatkan keterampilan berpikir luwes siswa pada materi asam basa yang ditunjukkan melalui nilai $n$ Gain dengan kriteria "tinggi" dan didukung dari hasil rata-rata persentase kemampuan guru dalam mengelola pembelajaran di kelas dengan kategori "sangat tinggi".

$\begin{array}{ccr}\text { Model } & \text { Problem } & \text { Based } \\ \text { Learningpada } & \text { prosesnya } & \text { dapat } \\ \text { dilaksanakan } & \text { dengan baik } & \text { melalui }\end{array}$
pendekatan saintifik.Pendekatan saintifik merupakan pendekatan pembelajaran yang mengadopsi langkah-langkah saintifik dalam memecahkan permasalahan dan membangun pengetahuan melalui metode ilmiah. Pendekatan ini memiliki langkah-langkah yang berkorelasi dengan model Problem Based Learning yakni mengamati, menanya, mencoba, mengasosiasi dan mengkomunikasikan. Pendekatan saintifik dimaksudkan untuk memberi pemahaman kepada siswa untuk mengetahui, memahami, mempraktikkan apa yang sedang dipelajari secara ilmiah (Musfiqon, 2015). Berdasarkan hasil penelitian Alman (2016) disimpulkan bahwa pendekatan saintifik menggunakan model Problem Based Learning dapat meningkatkan hasil belajar siswa kelas XI IPA MAN Bau-Bau pada materi pokok titrasi asam dan basa dengan $\mathrm{N}$ gain sebesar 0,61 (kategori sedang). 
Penggunaan model Problem Based Learning dengan pendekatan saintifik ini diharapkan dapat menarik minat dan kreativitas siswa untuk belajar kimia sehingga siswa menjadi aktif dan diharapkan hasil belajarnya akan meningkat, karena siswa diajak untuk mencari informasi, untuk mengembangkan keterampilan pemecahan masalah, melakukan penyelidikan dan percobaan untuk menemukan konsep tentang materi Asam Basa.

\section{METODE PENELITIAN}

Penelitian ini menggunakan metode Pre-Experimental dengan desain One Group Pretest-Posttest Design yaitu penelitian yang dilaksanakan pada satu kelompok saja tanpa ada kelompok pembanding. Desain ini dapat digambarkan seperti pada Tabel 1 berikut :

Tabel 1. Desain Penelitian

\begin{tabular}{cccc}
\hline Kelompok & $\begin{array}{c}\text { Pre- } \\
\text { test }\end{array}$ & Treatment & $\begin{array}{c}\text { Post- } \\
\text { test }\end{array}$ \\
\hline Eksperimen & $\mathrm{O}_{1}$ & $\mathrm{X}$ & $\mathrm{O}_{2}$ \\
\hline
\end{tabular}

Penelitian ini dilaksanakan melalui tiga tahap, yaitu: (1) tahap persiapan, (2) tahap pelaksanaan, dan (3) tahap pengolahan dan analisis data.

Variabel dalam penelitian ini yaitu: (1) Variabel bebas yaitu pembelajaran menggunakan model Problem Based Learning (PBL) dengan pendekatan saintifik. (2) Variabel terikat yaitu hasil belajar siswa setelah mengikuti pembelajaran menggunakan model Problem Based Learning (PBL) dengan pendekatan saintifik.
Instrumen yang digunakan dalam penelitian ini berupa : (1) tes hasil belajar, untuk memperoleh data hasil belajar siswa. Tes hasil belajar yang digunakan dalam penelitian ini adalah pilihan ganda yang terdiri dari 5 pilihan jawaban sebanyak 20 soal. (2) Lembar observasi untuk mengukur tingkat aktivitas atau partisipasi guru dan siswa dalam proses pembelajaran kimia menggunakan model PBL dengan pendekatan saintifik; (3) Angket digunakan untuk mengetahui tanggapan siswa terhadap model Problem Based Learning (PBL) dengan pendekatan saintifik, termasuk kesulitan-kesulitan yang dialami siswa.

Teknik pengumpulan data pada penelitian ini dilakukan dengan memberikan tes kepada siswa kelas eksperimen. Selain data hasil belajar, pengumpulan data pada penelitian ini juga dilakukan dengan lembar observasi aktivitas guru untuk memantau keterlaksanaan model pembelajaran dan lembar observasi aktivitas siswa selama proses pembelajaran serta angket tanggapan siswa terhadap model pembelajaran yang digunakan.

Nilai rata-rata yang diperoleh akan disajikan dalam bentuk tabel distribusi, sehingga dapat menggambarkan hasil belajar siswa sesuai dengan pedoman penilaian yaitu Penilaian Acuan Patokan (PAP) dari sekolah sebagai berikut :

1. $80 \leq X \leq 100$ (Tinggi)

2. $60 \leq X<80$ (Sedang)

3. $0 \leq X<60$ (Rendah)

Rumus menentukkan nilai ratarata hasil belajar :

$$
\bar{x}=\frac{\sum_{i=1}^{n} x_{i}}{n}
$$


Standar deviasi sering disebut dengan simpangan, merupakan suatu ukuran yang menggambarkan tingkat penyebaran data dari nilai rata-rata. Rumus yang digunakan untuk menghitung standar deviasi tersebut adalah sebagai berikut :

$$
S=\frac{\sum_{i=1}^{n}\left(x_{i}-\bar{x}\right)^{2}}{n-1}
$$

Keterangan:

$$
\begin{aligned}
& S=\text { Standar deviasi } \\
& \bar{x}=\text { Rata-rata nilai hasil belajar } \\
& x_{i}=\text { nilai setiap harga } x \\
& n=\text { jumlah sampel }
\end{aligned}
$$

Untuk melihat peningkatan hasil belajar siswa sebelum dan sesudah pembelajaran pada kelas eksperimen dihitung dengan menggunakan rumus $\mathrm{N}$-gain faktor (Gain Source Normalized) dengan rumus :

$N-$ gain $=\frac{S_{\text {postes }}-S_{\text {pretes }}}{S_{\text {max }}-S_{\text {pretes }}}$ (Meltzer, 2002)

Keterangan:

$$
\begin{aligned}
& N \text {-gain }=\mathrm{N} \text {-gain } \\
& S_{\text {postes }}=\text { skor } \text { post-test } \\
& S_{\text {pretes }}=\text { skor } \text { pre-test } \\
& S_{\text {maks }}=\text { skor maksimum ideal }
\end{aligned}
$$

Kriteria N-Gain ditentukan berdasarkan pada tabel berikut:

Tabel 2. Kriteria N-Gain

\begin{tabular}{ccc}
\hline No. & Rentang & Kriteria \\
\hline 1. & N-gain $>0,7$ & Tinggi \\
\hline 2. & $0,3 \leq \mathrm{N}$-gain $\leq 0,7$ & Sedang \\
\hline 3. & N-gain $<0,3$ & Rendah \\
\hline
\end{tabular}

Presentase keterlaksanaan pembelajaran diperoleh menggunakan persamaan berikut:

$$
P(\%)=\frac{\text { jumlah skor hasil observasi }}{\text { jumlah skor maksimal }} \times 100 \%
$$

Tabel 3. Presentase Keterlaksanaan

\begin{tabular}{cc}
\hline $\begin{array}{c}\text { Presentase } \\
\text { Keterlaksanaan } \\
\text { Pembelajaran }\end{array}$ & Kriteria \\
\hline $0,00 \%-24,9 \%$ & Sangat Kurang \\
\hline $25,0 \%-37,5 \%$ & Kurang \\
\hline $37,6 \%-62,5 \%$ & Sedang \\
\hline $62,6 \%-87,5 \%$ & Baik \\
\hline $87,6 \%-100 \%$ & Sangat baik \\
\hline
\end{tabular}

Data angket dianalisis dengan dengan rumus berikut :

$$
(\%)=\frac{\text { Jumlah skor yang diperoleh dari data }}{\text { Juml 牵h skor maksimal }} \times 100 \%
$$

Tabel 4. Presentase Respon Siswa

\begin{tabular}{cc}
\hline $\begin{array}{c}\text { Persentase respon } \\
\text { siswa }\end{array}$ & $\begin{array}{c}\text { Kriteria respon } \\
\text { siswa }\end{array}$ \\
\hline $0 \%-24,99 \%$ & Kurang \\
$25 \%-49,99 \%$ & Cukup \\
$50 \%-74,99 \%$ & Baik \\
$75 \%-100 \%$ & Sangat Baik \\
\hline
\end{tabular}

(Arikunto, 2002).

\section{HASIL DAN PEMBAHASAN}

Data hasil belajar kimia siswa kelas XI $\mathrm{MIA}_{3}$ SMA Negeri 7 Kendari setelah diajar dengan menggunakan model Problem Based Learning (PBL) dengan pendekatan saintifik dapat dilihat pada Tabel 4 berikut:

Tabel 5. Deskripsi Nilai

\begin{tabular}{lcc}
\hline \multirow{2}{*}{ Deskripsi Nilai } & \multicolumn{2}{c}{ Kelas XI MIA } \\
\cline { 2 - 3 } & Pre-test & Post-test \\
\hline Nilai Tertinggi & 45 & 95 \\
\hline Nilai Terendah & 15 & 60 \\
\hline Nilai Rata-rata & 29,42 & 78,46 \\
\hline Standar Deviasi & 8,04 & 9,98 \\
\hline Median & 30 & 80 \\
\hline Modus & 35 & 75 \\
\hline $\begin{array}{l}\text { Jumlah Siswa } \\
\text { (n) }\end{array}$ & 26 & 26 \\
\hline
\end{tabular}

Berdasarkan uraian data hasil analisis pada Tabel 5 menunjukkan adanya perbedaan antara nilai hasil 
belajar siswa sebelum diberikan perlakuan (pre-test) berupa penerapan model PBL dengan pendekatan saintifik dan nilai hasil belajar siswa setelah diberikan perlakuan (post-test). Berdasarkan data yang diperoleh dari hasil penelitian, nilai rata-rata pre-test adalah 29,42 dan pada saat post-test adalah 78,46 . Nilai yang diperoleh pada saat pre-test ke post-test meningkat sebesar 49,04. Untuk nilai rata-rata post-test yang diperoleh sebesar 78,46 menunjukkan bahwa nilai hasil belajar yang diperoleh sudah berada diatas nilai KKM yang ditetapkan sekolah yaitu 75 .

Standar deviasi nilai pre-test adalah 8,04 dan pada saat post-test adalah 9,98 dari data ini dapat dilihat perbedaan keberagaman nilai siswa, dimana keberagaman nilai pre-test siswa lebih rendah dibandingkan keberagaman nilai post-test siswa. Nilai tertinggi untuk pre-test adalah 45, sedangkan nilai tertinggi untuk post-test adalah 95. Untuk nilai terendah, diperoleh nilai pre-test adalah 15 Sedangkan nilai post-test adalah 60 . Median untuk nilai pre-test adalah 30, sedangkan median untuk nilai post-test adalah 80. Berdasarkan data ini dapat disimpulkan bahwa ada perbedaan hasil belajar siswa sebelum dan sesudah perlakuan.

Perbedaan nilai rata-rata antara pre-test dan post-test siswa kelas XI $\mathrm{MIA}_{3}$ ini jugandisebabkan karena penguasaan konsep atau pengetahuan awal siswa mengenai materi Asam Basa masih sangat kurang sehingga ketika peneliti memberikan pre-test, siswa belum mampu menjawab atau menyelesaikan soal-soal yang diberikan dengan baik, bahkan tidak menutup kemungkinan siswa hanya memilih opsi jawaban dengan asal ketika diberikan soal pre-test karena soal yang diberikan berupa soal pilihan ganda. Hal ini dikarenakan siswa belum mengetahui konsep Asam Basa yang diberikan walaupun ada beberapa siswa yang pernah melihat bahkan menggunakannya dalam kehidupan sehari-hari. Sedangkan setelah diberi perlakuan berupa penerapan model PBL dengan pendekatan saintifik sebagian besar siswa telah mampu menyelesaikan atau menjawab soal-soal tes dengan benar.

Berdasarkan pedoman pengkategorian nilai hasil belajar siswa, klasifikasi hasil belajar siswa dapat dilihat pada tabel 6 berikut :

Tabel 6. Pedoman Pengkategorian Nilai Hasil Belajar

\begin{tabular}{cccccc}
\hline \multirow{2}{*}{ Nilai } & Katego & \multicolumn{2}{c}{ Pre-test } & \multicolumn{2}{c}{ Post-test } \\
\cline { 3 - 6 } & ri & F & \% & F & $\%$ \\
\hline $80 \leq X \leq 100$ & Tinggi & 0 & 0 & 14 & 54 \\
\hline $60 \leq X<80$ & Sedang & 0 & 0 & 12 & 46 \\
\hline $0 \leq X<60$ & Rendah & 26 & 100 & 0 & 0 \\
\hline Jumlah & & 26 & 100 & 26 & 100 \\
\hline
\end{tabular}

Tabel 6 menunjukkan tingkat penguasaan siswa terhadap materi Asam Basa sebelum diberikan materi pelajaran Asam Basa oleh guru (pretest) dan penguasaan siswa setelah diberikan materi pelajaran Asam Basa dengan menggunakan model PBL dengan pendekatan saintifik (post-test) ditinjau dari hasil belajar kimia. Berdasarkan data diatas, siswa yang berada pada kategori rendah $(0 \leq \mathrm{X}<$ 60) pada saat pre-test sebanyak 26 orang atau $100 \%$. Pada saat pemberian pre-test kemampuan awal siswa atau penguasaan konsep yang dimiliki oleh siswa masih sangat kurang. Siswa diberikan tes awal (pre-test) tanpa diberi perlakuan sebelumnya berupa model dan pendekatan pembelajaran sehingga siswa belum mampu menjawab soal-soal yang diberikan 
dengan baik. Selanjutnya pada saat pemberian post-test, siswa yang berada pada kategori tinggi $(80 \leq \mathrm{X} \leq 100)$ yaitu 14 orang atau $54 \%$, pada kategori sedang $(60 \leq X<80)$ yaitu 12 orang atau $46 \%$ dan tidak ada siswa yang berada pada kategori rendah. Dengan demikian nilai rata-rata post-test siswa terlihat pada kategori sedang karena siswa sudah diberikan perlakuan model PBL dengan pendekatan saintifik.

Persentase ketuntasan belajar siswa setelah proses pembelajaran menggunakan model PBL dengan pendekatan saintifik dapat dilihat pada tabel 7 berikut:

Tabel 7. Presentase proses pembelajaran menggunakan model PBL dengan pendekatan saintifik

\begin{tabular}{clcc}
\hline Nilai & Kategori & F & Persentase \\
\hline $75 \leq X \leq 100$ & Tuntas & 19 & $73 \%$ \\
\hline $0 \leq X<75$ & Tidak & 7 & $27 \%$ \\
& Tuntas & & \\
\hline
\end{tabular}

Berdasarkan

Tabel

7

menunjukkan bahwa persentase hasil belajar siswa yang tuntas sebanyak 19 orang atau $73 \%$ dan siswa yang tidak tuntas sebanyak 7 orang atau $27 \%$. Persentase siswa yang mencapai Kriteria Ketuntasan Minimal (KKM) yang besar menunjukkan adanya pengaruh dari model PBL dengan pendekatan saintifik yang digunakan sehingga mampu meningkatkan hasil belajar siswa kelas XI MIA 3 pada materi asam basa.

Peningkatan hasil belajar siswa kelas XI MIA 3 SMAN 7 Kendari dapat dilihat dari $\mathrm{N}$-gain yang diperoleh. Analisis $N$-gain diperlukan untuk mengetahui efektivitas model pembelajaran yang diterapkan. Hasil analisis $\mathrm{N}$-gain yang diperoleh dapat dilihat pada Tabel 8 berikut:
Tabel 8. Peningkatan hasil belajar siswa kelas XI MIA 3 SMAN 7

\begin{tabular}{|c|c|c|c|c|}
\hline Nilai Indeks Gain & $\mathbf{F}$ & $\%$ & $\begin{array}{l}\text { Rata- } \\
\text { rata }\end{array}$ & Kategori \\
\hline $\begin{array}{r}\text {-gain }>0,7 \\
\text { (Tinggi) }\end{array}$ & 12 & 46 & \multirow{3}{*}{0,70} & \multirow{3}{*}{ Sedang } \\
\hline $\begin{array}{l}0,3 \leq N \text {-gain } \leq 0,7 \\
(\text { Sedang) }\end{array}$ & 14 & 54 & & \\
\hline $\begin{aligned} N \text {-gain } & <0,3 \\
& \text { (Rendah) }\end{aligned}$ & 0 & 0 & & \\
\hline
\end{tabular}

Berdasarkan Tabel 8. dapat dilihat bahwa terdapat 12 orang siswa yang memperoleh nilai $N$-gain dengan kategori tinggi dengan persentase sebesar $46 \%$, sedangkan 14 orang siswa lainnya memperoleh $\mathrm{N}$-gain dengan kategori sedang dengan persentase sebesar 54\% dan tidak ada siswa yang memperoleh $\mathrm{N}$-gain dengan kategori rendah. Berdasarkan data hasil belajar siswa dan $\mathrm{N}$-gain yang diperoleh siswa secara individu ini, dapat dinyatakan bahwa model PBL dengan pendekatan saintifik dapat meningkatkan hasil belajar kimia siswa kelas XI $\mathrm{MIA}_{3}$ SMAN 7 Kendari pada materi Asam Basa apabila dilihat dari perbedaan hasil belajar antara pre-test dan post-test.

Rata-rata nilai $N$-gain yang diperoleh secara keseluruhan siswa kelas XI $\mathrm{MIA}_{3}$ berdasarkan Tabel 9, rata-rata $N$-gain siswa adalah 0,70 dan berada pada kategori sedang. Hal ini menunjukkan bahwa hasil belajar kimia siswa yang diajarkan dengan model PBL dengan pendekatan saintifik efektif untuk diterapkan pada materi Asam Basa, dimana semakin tinggi $\mathrm{N}$-gain maka semakin efektif model yang digunakan. Hal ini didukung pula dengan hasil penelitian (Alman, 2016) pada siswa MAN Bau-Bau pada materi titrasi Asam Basa menunjukkan bahwa peningkatan hasil belajar siswa setelah pembelajaran dengan pendekatan saintifik menggunakan model PBL 
lebih besar dibandingkan dengan siswa setelah pembelajaran dengan model konvesional.

Hasil observasi aktivitas siswa kelas XI $\mathrm{MIA}_{3}$ SMAN 7 Kendari selama proses pembelajaran dengan menggunakan model PBL dengan pendekatan saintifik dapat dilihat pada tabel 9 berikut :

Tabel 9. Hasil observasi aktivitas siswa kelas XI MIA 3 SMAN 7 Kendari

\begin{tabular}{ccc}
\hline Pertemuan & Aktivitas siswa & Kriteria \\
\hline I & $75,00 \%$ & Baik \\
\hline II & $80,77 \%$ & Baik \\
\hline III & $82,69 \%$ & Baik \\
\hline IV & $84,62 \%$ & Baik \\
\hline $\begin{array}{c}\text { Rata- } \\
\text { rata }\end{array}$ & $\mathbf{8 0 , 7 7 \%}$ & Baik \\
\hline
\end{tabular}

Tabel 9. Menunjukkan aktivitas siswa atau persentase keterlibatan siswa selama pembelajaran dengan menerapkan model pembelajaran PBL dengan pendekatan saintifik mengalami peningkatan dari pertemuan 1 sampai dengan pertemuan IV. Menurut Afif (2014) ketertarikan siswa terhadap pembelajaran yang dibawakan oleh guru merupakan salah satu faktor yang menyebabkan siswa berperan aktif dalam proses pembelajaran. Oleh karena itu, jika siswa merasa kurang tertarik dalam proses pembelajaran maka aktivitas siswa pun akan rendah, begitu pula sebaliknya jika siswa merasa tertarik dalam proses belajar mengajar maka aktivitas siswa pun akan tinggi (Sari, 2015).

Berdasarkan Tabel 10 dapat dilihat data hasil observasi aktivitas siswa, dimana pada pertemuan pertama dapat terlihat bahwa aktivitas siswa yaitu $75 \%$ yang termasuk dalam kategori baik. Meskipun dalam kategori baik namun masih banyak aspek yang belum maksimal dilaksanakan serta masih butuh perbaikan. Pada pertemuan pertama, siswa masih memerlukan penyesuaian dengan model pembelajaran yang diterapkan. Terlihat bahwa belum semua siswa dapat berbagi tugas dalam kelompoknya dalam mencari informasi pada pemecahan masalah. Siswa juga masih harus dibimbing dalam merumuskan masalah dan juga hipotesis seputar fenomena yang disajikan.

Pada pertemuan kedua aktivitas menjadi $80,77 \%$ yang termasuk dalam kategori baik. Pada pertemuan kedua ini siswa sudah mulai terbiasa belajar dengan menggunakan model PBL dengan pendekatan saintifik. Siswa mulai berinisiatif untuk terlibat aktif selama proses pembelajaran berlangsung, dimulai dari mencari dan menentukkan masalah dengan mengamati gambar yang disajikan guru, mengajukan hipotesis hingga dalam proses penyelidikan atau melakukan praktikum. Siswa sudah mulai terbiasa berbagi tugas dalam kelompok serta aktif mengungkapkan pendapat selama pembelajaran berlangsung. Selanjutnya pada pertemuan ketiga dan keempat mengalami peningkatan dimana pada pertemuan ketiga sebesar $82,69 \%$ yang termasuk kategori baik dan pada pertemuan keempat menjadi 84,62\% yang termasuk dalam kategori baik. Peningkatan ini menunjukkan bahwa siswa dapat mengembangkan pengetahuannya secara mandiri dengan penuh percaya diri untuk memecahkan masalah guna mendapatkan konsepkonsep penting dan pengetahuan baru serta mampu untuk berpikir kritis.

Berdasarkan analisis hasil observasi siswa, ketercapaian seluruh aspek yang diamati adalah sebesar $80,77 \%$ termasuk dalam kategori baik. Dengan demikian dapat disimpulkan 
bahwa aktivitas siswa dalam proses pembelajaram meningkat secara berturut-turut dari pertemuan pertama sampai dengan pertemun keempat dalam satu rangkaian kegiatan belajar menggunakan model PBL dengan pendekatan saintifik. Selain itu siswa juga memerlukan waktu untuk beradaptasi terhadap suatu pembelajaran yang baru, baik materi maupun model pembelajaran serta pendekatan yang digunakan.

Peningkatan aktivitas siswa yang diperoleh menunjukkan bahwa siswa dapat menerima dengan baik penerapan model PBL dengan pendekatan saintifik di dalam kelas. Hal ini diperkuat oleh Wicaksono (2012) bahwa siswa memiliki minat terhadap suatu objek tertentu cenderung memberikan perhatian yang besar terhadap suatu objek tersebut.

Hasil observasi aktivitas guru selama proses pembelajaran dapat dilihat pada tabel 10 berikut:

Tabel 10. Hasil observasi aktivitas guru

\begin{tabular}{ccc}
\hline Pertemuan & $\begin{array}{c}\text { Aktivitas } \\
\text { Guru }\end{array}$ & Kriteria \\
\hline I & $85,0 \%$ & Baik \\
\hline II & $90,0 \%$ & Sangat Baik \\
\hline III & $92,5 \%$ & Sangat Baik \\
\hline IV & $95,0 \%$ & Sangat Baik \\
\hline Rata-rata & $\mathbf{9 0 , 6 \%}$ & Sangat Baik \\
\hline
\end{tabular}

Tabel 10 menunjukkan aktivitas guru atau persentase keterlaksanaan model PBL dengan pendekatan saintifik yang dilakukan guru mengalami peningkatan pada pertemuan I sampai dengan pertemuan IV. Berdasarkan data hasil observasi aktivitas guru pada Tabel 4.6 terlihat bahwa pada pertemuan pertama aktivitas guru yaitu $85 \%$ dan termasuk dalam kategori baik. Pada pertemuan pertama guru masih menyesuaikan kondisi siswa, sehingga walaupun presentasi kegiatan pembelajaran sudah termasuk dalam kategori baik namun masih ada beberapa aspek yang belum maksimal dilaksanakan serta masih butuh perbaikan dalam orientasi siswa terhadap permasalahan, hal ini disebabkan karena siswa masih bersifat acuh terhadap proses pembelajaran, sehingga guru masih kesulitan mengarahkan siswa berdiskusi tentang permasalahan yang ada dalam LKS.

Pada pertemuan kedua persentase keterlaksanaan kegiatan pembelajaran guru meningkat menjadi $90,0 \%$ dalam melakukan pengajaran. Pada pertemuan ketiga dan pertemuan keempat juga mengalami peningkatan dimana pada pertemuan ketiga menjadi $92,5 \%$ dan pada pertemuan keempat menjadi $95,0 \%$. Peningkatan ini terjadi karena guru sudah mulai menyesuaikan dengan kondisi siswa selama proses pembelajaran, serta guru sudah dapat membimbing siswa untuk belajar selama proses pembelajaran berlangsung. Rata-rata aktivitas pembelajaran pada guru yaitu 90,6\% yang termasuk dalam kategori sangat baik. Hal ini menunjukkan bahwa sintaks dari model PBL dengan pendekatan saintifik yang diterapkan terlaksana dengan baik.

Analisis angket respon siswa terhadap model pembelajaran PBL dengan pendekatan saintifik pada pokok materi Asam Basa dapat dilihat pada Tabel 11 berikut :

\begin{tabular}{cccc}
\hline No. & $\begin{array}{c}\text { Kecenderungan } \\
\text { Respon Siswa }\end{array}$ & Persentase & $\begin{array}{c}\text { Kriteria } \\
\text { Interprestasi }\end{array}$ \\
\hline 1 & $3-4$ & $89,42 \%$ & Sangat Baik \\
\hline 2 & $2-4$ & $87,50 \%$ & Sangat Baik \\
\hline 3 & $2-4$ & $76,92 \%$ & Sangat Baik \\
\hline 4 & $2-4$ & $82,69 \%$ & Sangat Baik \\
\hline 5 & $2-4$ & $89,42 \%$ & Sangat Baik \\
\hline 6 & $2-4$ & $84,62 \%$ & Sangat Baik \\
\hline 7 & $2-4$ & $83,65 \%$ & Sangat Baik \\
\hline
\end{tabular}




\begin{tabular}{cccc}
\hline 8 & $1-4$ & $80,77 \%$ & Sangat Baik \\
\hline 9 & $2-4$ & $78,85 \%$ & Sangat Baik \\
\hline 10 & $1-4$ & $76,92 \%$ & Sangat Baik \\
\hline 11 & $1-4$ & $86,54 \%$ & Sangat Baik \\
\hline 12 & $2-4$ & $80,77 \%$ & Sangat Baik \\
\hline 13 & $2-4$ & $78,85 \%$ & Sangat Baik \\
\hline 14 & $2-4$ & $86,54 \%$ & Sangat Baik \\
\hline 15 & $2-4$ & $80,77 \%$ & Sangat Baik \\
\hline & Rata - rata & $\mathbf{8 2 , 9 5 \%}$ & Sangat Baik \\
\hline
\end{tabular}

Berdasarkan hasil analisis angket respon siswa terhadap pembelajaran menggunakan model PBL dengan pendekatan saintifik diperoleh bahwa $89,42 \%$ siswa menyatakan pelajaran kimia yang diajar dengan model PBL dengan pendekatan saintifik sangat menyenangkan, dan sebagian besar siswa sangat setuju bahwa model PBL dengan pendekatan saintifik meningkatkan minat mereka dalam mempelajari konsep asam basa. Kemudian 76,92\% siswa menyatakan bahwa LKS yang diberikan memudahkan mereka dalam memahami materi asam basa, dan sebagian besar siswa setuju bahwa mereka termotivasi untuk menyelesaikan permasalahan yang diberikan dalam pembelajaran menggunakan model PBL dengan pendekatan saintifik.

Hasil analisis data angket respon siswa diperoleh nilai rata-rata keseluruhan respon siswa terhadap pembelajaran menggunakan model PBL dengan pendekatan saintifik diperoleh sebesar $82,95 \%$ yang termasuk dalam kategori sangat baik. Hal ini menunjukkan bahwa siswa tertarik dalam proses pembelajaran menggunakan model PBL dengan pendekatan saintifik yang mana model yang diterapkan peneliti membuat siswa aktif dalam proses pembelajaran sehingga siswa termotivasi untuk terlibat aktif dalam kegiatan pembelajaran yang mengindikasikan meningkatnya hasil belajar siswa setelah diajar dengan model pembelajaran tersebut.

Hubungan antara respon siswa terhadap peningkatan hasil belajar siswa $(N$-gain) dapat dilihat dari nilai rata-rata keduanya. Dari data yang diperoleh menunjukkan bahwa efektivitas penerapan model PBL dengan pendekatan saintifik dalam pembelajaran tergolong dalam kategori sedang dengan rata-rata sebesar 0,70 efektif menunjukkan peningkatan hasil belajar siswa, begitupun dengan respon siswa terhadap model PBL dengan pendekatan saintifik maupun materi kimia dalam pembelajaran Asam Basa tergolong sangat baik dengan nilai ratarata $82,95 \%$. Peningkatan hasil belajar siswa juga diperkuat dengan data aktivitas siswa selama proses pembelajaran yang masuk dalam kategori baik.

\section{KESIMPULAN DAN SARAN}

1. Hasil belajar kimia siswa kelas XI $\mathrm{MIA}_{3}$ SMA Negeri 7 Kendari Tahun Ajaran 2018/2019 sebelum pembelajaran dengan menggunakan model PBL dengan pendekatan saintifik hasil belajar siswa dikategorikan rendah dengan nilai rata-rata yaitu sebesar 29,42 akan tetapi setelah pembelajaran dengan menggunakan model PBL dengan pendekatan saintifik hasil belajar siswa dikategorikan sedang dengan nilai rata-rata posttest sebesar 78,46.

2. Penerapan model PBL dengan pendekatan saintifik pada materi Asam Basa efektif dalam meningkatkan hasil belajar siswa, dengan rata-rata $N$-gain sebesar 0,70 yang termasuk dalam kategori sedang. 
3. Respon siswa terhadap penerapan model PBL dengan pendekatan saintifik pada materi Asam Basa termasuk dalam kategori sangat baik $(82,95 \%)$

\section{DAFTAR PUSTAKA}

Alman, La Ode. 2016. Keefektifan Pendekatan Saintifik Menggunakan Media Berbasis Model Problem Based Learning (PBL) untuk Meningkatkan $\mathrm{H}$ asil Belajar Siswa Kelas XI IPA MAN Bau-Bau pada Materi Pokok Titrasi Asam Basa. Skripsi. Kendari: FKIP UHO.

Arikunto, Suharsimi. 2002. Dasar Dasar Evaluasi Pendidikan. Jakarta: Bumi Aksara

Kemendikbud. 2013. Konsep Pendekatan Saintifik. Diklat Guru dalam Implementasi Kurikulum 2013.

Meltzer, D. E. 2002. The Relationship Between Mathematics Preparation and Conceptual Learning Gain in Physics: A possible "Hidden Variable" in Diagnostic Pretest Scores. American Journal of Physics. 70(12): 1259-1268.

Musfiqon \& Nurdyansyah. 2015. Pendekatan Pembelajaran Saintifik. Sidoarjo: Nizamia Learning Center.

Ruseffendi. 1998. Statistika Dasar untuk Penelitian Pendidikan. Bandung: IKIP Bandung Press.

Sari, Y. A. 2015. Efektivitas Model Pembelajaran Berbasis Masalah
(PBM) terhadap Hasil Belajar Siswa Kelas XI MIA 1 SMA Negeri 1 Pondidaha pada Pokok Bahasan Termokimia. Skripsi. Kendari: FKIP UHO.

Sudjana, Nana. 2002. Metode Statistika.Bandung: Tarsito.

Suryabrata, Sumadi. 2005. Metodologi Penelitian. Jakarta: Raja Grafinda Persada.

Wicksono, A. 2012. Efektivitas Teknik Keaktoran dalam Pembelajaran Drama terhadap Kemampuan Memerankan Tokoh dalam Pementasan Ditinjau dari Minat Berlatih Drama. Skripsi. Solo: Universitas Sebelas Maret 